\title{
ANALISIS SINTASAN PARAMETRIK PADA PASIEN STROKE DENGAN PENDEKATAN DISTRIBUSI WEIBULL
}

\author{
Ni Made Sri Wahyuni ${ }^{1 \S}$, I Wayan Sumarjaya ${ }^{2}$ Ni Luh Putu Suciptawati ${ }^{3}$ \\ ${ }^{1}$ Program Studi Matematika, Fakultas MIPA - Universitas Udayana [Email: madesri80@gmail.com] \\ ${ }^{2}$ Program Studi Matematika, Fakultas MIPA - Universitas Udayana [Email: sumarjaya@unud.ac.id] \\ ${ }^{3}$ Program Studi Matematika, Fakultas MIPA - Universitas Udayana [Email: suciptawati@ unud.ac.id] \\ ${ }^{\S}$ Corresponding Author
}

\begin{abstract}
Parametric survival analysis is one of the survival analysis that has a distribution of survival data that follows a certain distribution. Weibull distribution is a distribution that is often used in parametric survival analysis. The purpose of this study is to determine parametric survival models using the Weibull distribution and to determine the factors that can influence the recovery of stroke patients. This study uses data on stroke patients in the Wangaya hospital, Denpasar in 2017. The best model obtained in this study is a model that consists of two predictor variables, namely the age and the body mass index (BMI).Therefore the factors that can influence the recovery of stroke patients are age and BMI.
\end{abstract}

Keywords: Parametric survival analysis, stroke, Weibull.

\section{PENDAHULUAN}

Stroke merupakan penyakit yang terjadi pada otak yang menyebabkan gangguan fungsi saraf lokal atau global dengan kemunculan yang mendadak, progresif, dan cepat (Kemenkes, 2013). Menurut WHO (2016) secara global stroke merupakan penyebab kematian kedua dan penyebab keenam dari kecacatan.

Jumlah kasus stroke di Indonesia berdasarkan diagnosis kesehatan sebesar 7 kasus per mil dan yang terdiagnosis tenaga kesehatan atau gejala sebesar 12,1 kasus per mil. Jumlah kasus stroke di Bali berdasarkan diagnosis tenaga kesehatan yaitu sebesar 5,3\% dan berdasarkan terdiagnosis tenaga kesehatan dan gejala yaitu sebesar 8,9\%o (Kemenkes, 2013).

Faktor-faktor yang memengaruhi stroke dapat dikategorikan menjadi dua yaitu faktor risiko yang tidak dapat diubah dan faktor risiko yang dapat diubah. Faktor risiko yang tidak dapat diubah yaitu usia, jenis kelamin, ras atau bangsa, serta faktor riwayat stroke yang diturunkan dari keluarga. Sedangkan faktor risiko yang dapat diubah yaitu seperti hipertensi, diabetes melitus, penyakit jantung, TIA (transient ischaemic attack), obesitas, kebiasaan merokok, alkohol, stres, penyalahgunaan obat, dan lain-lain.

Penelitian tentang penyakit stroke telah dilakukan oleh beberapa peneliti diantaranya penelitian yang dilakukan oleh Ghani, dkk. (2016) mengenai faktor risiko dominan penderita stroke di Indonesia dan penelitian yang dilakukan oleh Wulandari (2011) yang menerapkan metode least absolute shrinkage (LASSO).

Salah satu analisis yang dapat digunakan untuk menduga faktor-faktor yang memengaruhi kesembuhan pasien penyakit stroke adalah analisis sintasan. Analisis sintasan merupakan salah satu metode statistika yang digunakan untuk menganalisis data, di mana variabel yang diperhatikan adalah waktu sampai dengan terjadinya suatu peristiwa tertentu (Kleinbaum \& Klein, 2005).

Analisis sintasan parametrik adalah salah satu analisis sintasan yang memiliki sebaran data waktu sintasan dengan mengikuti suatu 
distribusi tertentu seperti distribusi Weibull, eksponensial, log-logistik, lognormal, dan generalisasi gamma (Kleinbaum \& Klein, 2005). Dalam analisis sintasan parametrik estimasi yang diperoleh dari model menghasilkan plot yang lebih konsisten. Selain itu, parameter dapat ditentukan menggunakan distribusi yang mendasari, sehingga fungsi sintasan dan fungsi hazard dapat ditentukan. Kesederhanaan dan kelengkapan inilah yang membuat analisis sintasan parametrik menarik untuk digunakan.

Penelitian tentang analisis sintasan parametrik telah dilakukan oleh beberapa peneliti. Bastyan \& Latra (2013) melakukan penelitian tentang analisis sintasan dengan model regresi Cox Weibull pada penderita demam berdarah dengue (DBD) di rumah sakit Haji Sukolilo Surabaya. Yogesswara dkk. (2018) melakukan penelitian tentang estimasi sintasan penderita diabetes melitus dengan komparasi kinerja regresi PLS dan LASSO. Selain itu, Monica \& Purhadi (2016) melakukan penelitian mengenai analisis faktor yang memengaruhi laju kesembuhan pasien tuberkulosis paru di RSUD Dr. Soetomo tahun 2015 menggunakan regresi Weibull dan regresi Cox Proportional Hazard.

Tujuan dari penelitian ini adalah untuk mengetahui model sintasan parametric dengan pendekatan distribusi Weibull dan untuk mengetahui faktor-faktor yang memengaruhi kesembuhan pasien penyakit stroke.

Menurut Kleinbaum \& Klein (2005) di dalam analisis sintasan terdapat data tersensor yang harus diperhatikan. Penyebab munculnya data tersensor yaitu:

1. Individu tidak mengalami kejadian hingga penelitian berakhir.

2. Individu hilang dari penelitian dalam periode penelitian.

3. Individu mengeluarkan diri dari penelitian karena kematian (jika kematian bukan kejadian yang diperhatikan) atau karena suatu alasan tertentu.

Distribusi waktu dalam analisis sintasan dapat dijelaskan dengan tiga fungsi yaitu fungsi sintasan (survivorship function), fungsi densitas probabilitas (probability density function), dan fungsi hazard (hazard function). Ketiga fungsi tersebut memiliki keterkaitan satu sama lain. Jika salah satu fungsi sudah diketahui maka kedua fungsi lainnya akan dapat dicari.

1. Fungsi Sintasan

$$
S(t)=1-\int_{0}^{t} f(u) d u \text {. }
$$

2. Fungsi Densitas Probabilitas

$$
\begin{aligned}
& f(t)= \\
& \lim _{\Delta t \rightarrow 0} \frac{P[\text { seorang individu mati dalam interval }(t, t+\Delta t)]}{\Delta t} . \\
& \text { (2) }
\end{aligned}
$$

3. Fungsi Hazard

$$
h(t)=\frac{f(t)}{1-F(t)} \text {. }
$$

Model regresi Cox merupakan model yang paling populer digunakan dalam analisis sintasan karena rasio hazard bisa ditentukan tanpa mengetahui baseline hazard, estimasi koefisien regresinya baik, kurva sintasan dapat diperoleh untuk berbagai macam data (Kleinbaum \& Klein, 2005). Persamaan model untuk Cox proportional hazard yaitu:

$h(t, X)=h_{0}(t) \exp \left(\sum_{i=1}^{p} \beta_{i} x_{i}\right)$.

dengan $h_{0}(t)$ adalah baseline hazard yang tidak perlu diketahui, $x_{i}$ adalah peubah-peubah bebas terdiri dari $x_{1}, x_{2}, x_{3}, \ldots, x_{p}$, dan $\beta_{i}$ adalah parameter dari peubah-peubah bebas terdiri dari $\beta_{1}, \beta_{2}, \beta_{3}, \ldots, \beta_{p}$.

Analisis sintasan parametrik adalah salah satu analisis sintasan yang mana sebaran data waktu sintasannya mengikuti suatu distribusi tertentu. Contoh dari distribusi yang umum digunakan untuk analisis sintasan parametrik adalah Weibull, eksponensial (kasus khusus dari Weibull), log-logistik, lognormal, dan generalisasi gamma (Kleinbaum \& Klein, 2005).

Model distribusi Weibull adalah model sintasan yang paling banyak digunakan. Bentuk umum fungsi hazard dari distribusi Weibull diberikan sebagai berikut (Kleinbaum \& Klein, 2005).

$$
h(t)=\lambda p t^{p-1} .
$$

Fungsi sintasan pada distribusi Weibull yaitu:

$$
S(t)=\exp \left(-\lambda t^{p}\right) .
$$

Fungsi densitas peluang distribusi hazard yaitu:

$$
f(t)=\lambda p t^{p-1} \exp \left(\lambda t^{p}\right) .
$$


Menurut Collet (1994) model proportional hazard distribusi Weibull dapat dinyatakan sebagai berikut:

$$
h_{i}(t)=\exp \left(\beta^{\prime} x\right) h_{0}(t) .
$$

dengan $h_{0}(t)=\lambda p t^{p-1}$ adalah baseline hazard yang dispesifikasikan pada parameternya dalam hal ini adalah distribusi Weibull.

Data yang diperoleh terdiri atas $n$ pengamatan waktu sintasan, ditunjukkan oleh $t_{1}, t_{2}, \ldots, t_{n} ; \delta_{i}$ adalah indikator sensor yang bernilai nol bila tersensor kanan untuk waktu sintasan ke- $i, t_{i}(1,2,3, \ldots, n)$ dan bernilai satu untuk yang lainnya. Maka fungsi likelihood dapat dinyatakan dalam bentuk:

$$
L(\beta)=\prod_{i=1}^{n}\left\{f_{i}\left(t_{i}\right)\right\}^{\delta}\left\{S_{i}\left(t_{i}\right)\right\}^{1-\delta} .
$$

dengan $f_{i}\left(t_{i}\right)$ adalah fungsi densitas dan $S_{i}\left(t_{i}\right)$ adalah fungsi sintasan.

Peubah yang berpengaruh terhadap model didapatkan melalui uji signifikansi parameter. Berikut ini pengujian parameter yang dilakukan setelah mendapatkan model (Lee, 1997).

Hipotesis:

$$
\begin{aligned}
& H_{0}: \beta_{i}=0, i=1,2,3, \ldots, p ; \\
& H_{1}: \beta_{i} \neq 0, i=1,2,3, \ldots, p .
\end{aligned}
$$

Statistik Uji:

Uji Wald yang berbentuk:

$$
\chi_{n}^{2}=\frac{\hat{\beta}_{i}}{S E\left(\hat{\beta}_{i}\right)} .
$$

Daerah kritis : Hipotesis nol $\left(\mathrm{H}_{0}\right)$ tidak diterima jika $\chi_{\text {hitung }}^{2}>\chi_{1, \alpha}^{2}$ atau jika P-value $<\alpha$.

\section{METODE PENELITIAN}

\subsection{Jenis dan Sumber Data}

Jenis data yang digunakan pada penelitian ini adalah berupa data sekunder. Data sekunder yang digunakan dalam penelitian ini adalah data yang sebelumnya telah dikumpulkan oleh Rumah Sakit Wangaya yang berupa data hasil rekam medis pasien penderita penyakit stroke yang dirawat inap pada tahun 2017.

\subsection{Variabel Penelitian}

Variabel respons yang digunakan pada penelitian ini adalah lama pasien penyakit stroke dirawat inap di Rumah Sakit Umum Daerah Wangaya, Denpasar tahun 2017. Variabel prediktor yang digunakan pada penelitian ini adalah usia $\left(\mathrm{X}_{1}\right)$, jenis Kelamin $\left(\mathrm{X}_{2}\right)$, jenis stroke $\left(\mathrm{X}_{3}\right)$, hipertensi $\left(\mathrm{X}_{4}\right)$, penyakit jantung $\left(\mathrm{X}_{5}\right)$, diabetes melitu $\left(\mathrm{X}_{6}\right)$, dan indeks massa tubuh (IMT) $\left(\mathrm{X}_{7}\right)$.

\subsection{Langkah-langkah Analisis}

Adapun langkah-langkah analisis yang akan dilakukan dalam penelitian ini yaitu:

1. Melakukan analisis deskriptif untuk melihat karakteristik dari pasię 2 pennyakit stroke yang dirawat inap di RSUD Wangaya tahun 2017.

2. Menguji asumsi proportional hazard menggunakan plot log minus log atau $\log (-\log (S(t))$ terhadap waktu sintasan untuk setiap variabel prediktor.

3. Melakukan pengujian distribusi Weibull pada variabel respons menggunakan uji Anderson-Darling.

4. Menyusun model proportional hazard Weibull.

5. Melakukan seleksi model terbaik dengan metode backward elimination serta melihat perubahan -2 log likelihood pada model yang dihasilkan dari pendekatan distribusi Weibull.

6. Melakukan pengujian secara parsial melalui pendekatan distribusi Weibull untuk mengetahui peranan masing-masing variabel prediktor terhadap variabel respons.

7. Mendapatkan model proportional hazard Weibull.

8. Interpretasi model proportional hazard Weibull.

\section{HASIL DAN PEMBAHASAN}

\subsection{Deskriptif Data}

Analisis deskriptif digunakan untuk menunjukkan karakteristik ataupun gambaran umum dari data yang telah diperoleh yaitu berupa data hasil rekam medis pasien stroke yang dirawat inap di Rumah Sakit Umum 
Daerah Wangaya Denpasar pada tahun 2017. Data yang digunakan dalam penelitian ini adalah sebanyak 100 data pasien stroke.

Persentase jumlah pasien stroke berdasarkan usia yaitu diperoleh persentase tertinggi pada usia 55-64 tahun dan 65-74 tahun dengan masing-masing persentase yaitu sebesar $26 \%$. Peningkatan usia berhubungan dengan proses penuaan yaitu semua organ tubuh mengalami kemunduran fungsi termasuk pembuluh darah otak (Kristyawati, dkk., 2009). Julmah pasien stroke berjenis kelamin laki-laki pada penelitian ini memiliki persentase yang lebih banyak yaitu sebesar 53\%, sedangkan jenis kelamin perempuan memiliki persentase sebesar $47 \%$. Menurut Krityawati, dkk. (2009) kondisi ini berhubungan dengan gaya hidup laki-laki seperti merokok dan konsumsi alcohol. Jenis stroke non hemoragik merupakan jenis stroke yang paling banyak terjadi yaitu sebesar $84 \%$. Hal tersebut sesuai dengan penelitian Dinata, dkk. (2013) yang memperoleh hasil bahwa jenis stroke non hemoragik lebih besar jumlahnya dibandingkan dengan jenis stroke non hemoragik.

Persentase jumlah pasien stroke berdasarkan hipertensi yaitu sebesar $62 \%$ pasien mengalami hipertensi. Menurut Khairatunnisa \& Sari (2017) efek jangka panjang dari hipertensi adalah kerusakan dinding arteri dan memudahkan pecahnya pembuluh darah. Pada penelitian ini persentase pasien dengan riwayat penyakit jantung hanya sebesar $10 \%$. Hal ini sesuai dengan penelitian yang dilakukan Kristiyawati, dkk (2009) yang memperoleh hasil bahwa pasien yang menderita penyakit jantung lebih sedikit dibandingkan dengan pasien yang tidak menderita penyakit jantung.

Selanjutnya persentase pasien yang memiliki riwayat diabetes mellitus yaitu sebesar $16 \%$. Hasil penelitian ini bertentangan dengan Udani (2013), selain itu, menurut Ramadany, dkk. (2013) terdapat hubungan diabetes mellitus dengan kejadian stroke iskemik di mana kadar glukosa darah yang berlebih akan mengganggu elastisitas pembuluh darah. Sebagian besar pasien pada penelitian ini yaitu sebesar 53\% memiliki indeks massa tubuh $18,5-24,9 \mathrm{~kg} / \mathrm{m}^{2}$. Menurut PERDOSSI (2011), obesitas merupakan salah satu faktor yang dapat mempermudah terjadinya penyakit stroke. Penelitian ini terdapat sebesar $21 \%$ pasien yang memiliki status gizi yang berlebih atau obesitas.

\subsection{Asumsi Pemodelan Proportional Hazard}

Pengujian asumsi proportional hazard setiap variabel prediktor terhadap waktu sintasan dapat dilakukan dengan plot log minus log (LML). Variabel prediktor yang memberikan hasil plot LML yang sejajar dikatakan memenuhi asumsi proportional hazard dan dapat digunakan dalam model proportional hazard Weibull. Gambar 1 menunjukkan bahwa ketujuh variabel prediktor yang digunakan dalam penelitian ini proporsional sehingga dapat digunakan dalam model proportional hazard Weibull.

\subsection{Uji Distribusi Weibull}

Uji distribusi dilakukan untuk mengetahui distribusi data variabel respons (waktu sintasan). Pengujian distribusi dapat menggunakan uji distribusi Anderson-Darling. Berdasarkan Gambar 2 dapat dilihat bahwa nilai P-value > 0,05 , hal ini berarti waktu sintasan pasien stroke berdistribusi Weibul.

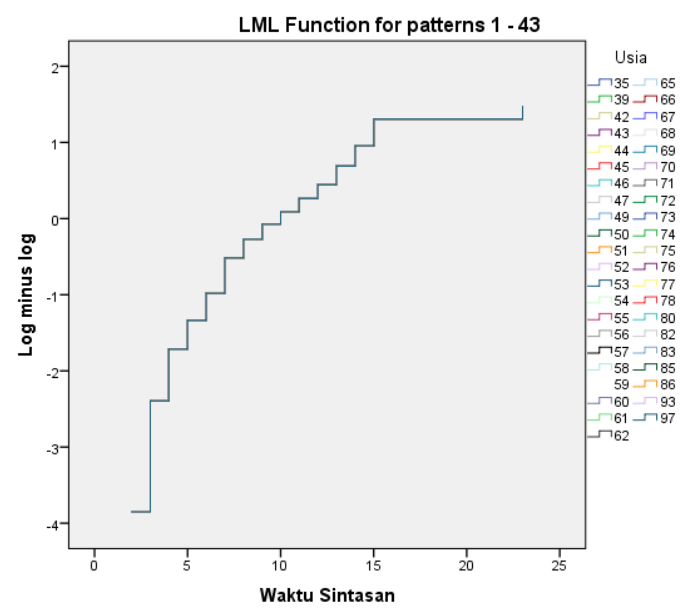



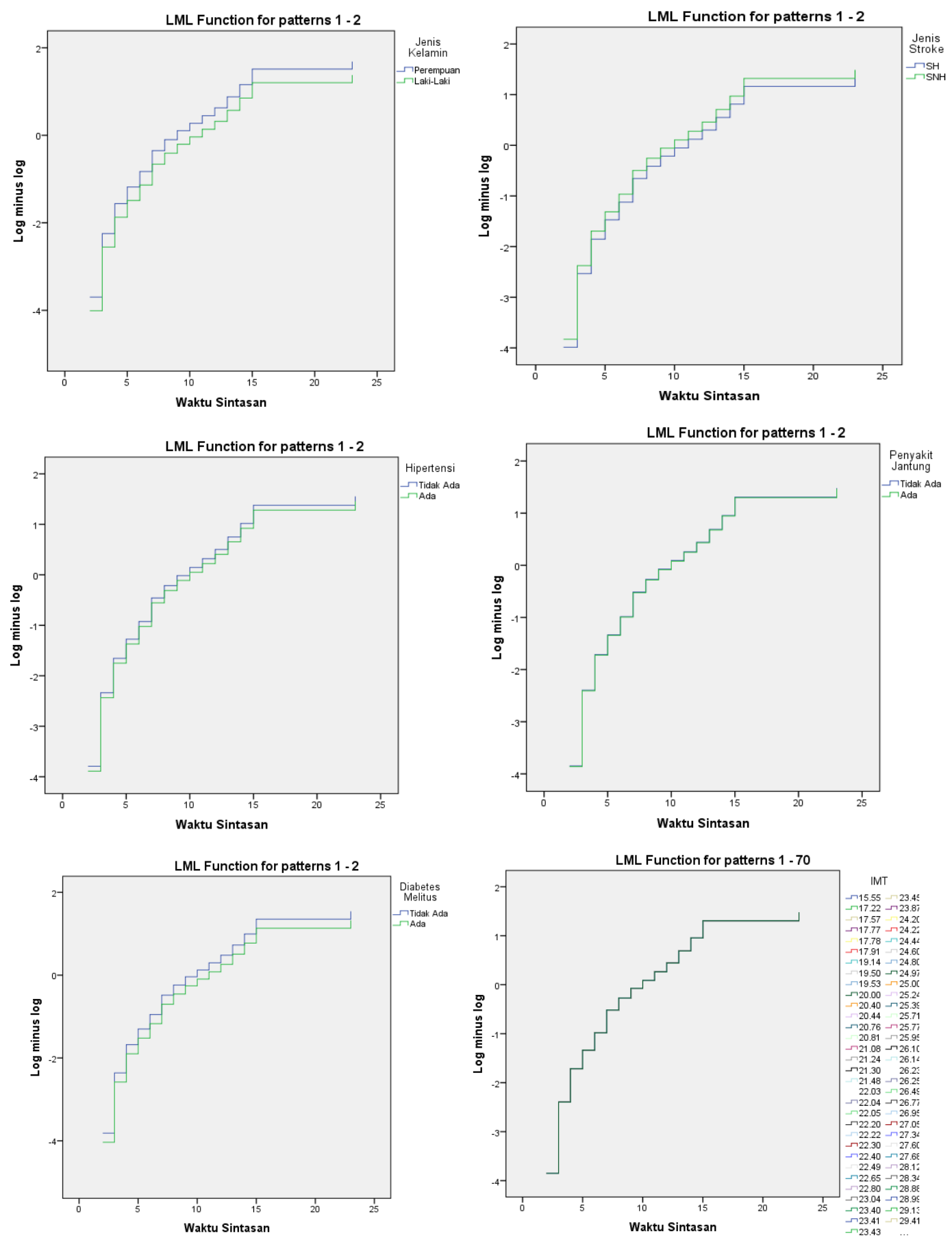

Gambar 1. Plot LML Waktu Sintasan Terhadap Ketujuh Variabel. 


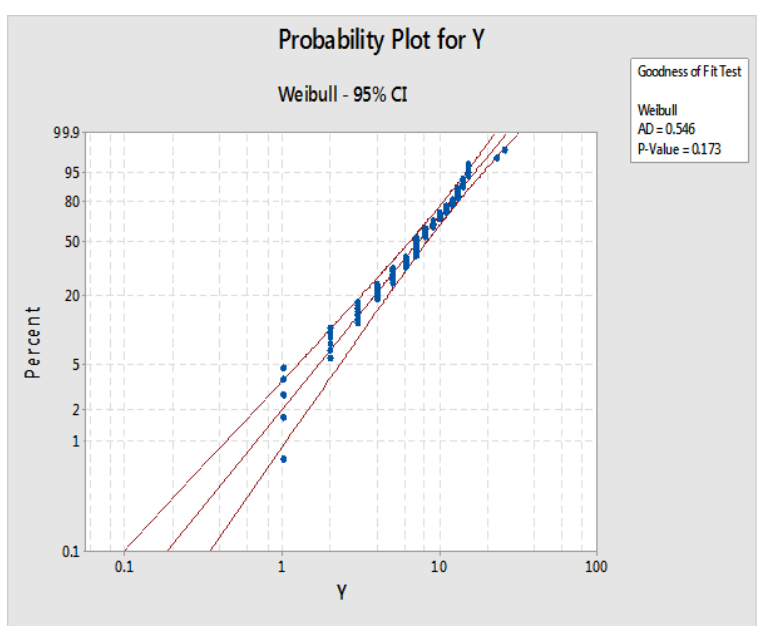

Gambar 2. Plot Distribusi Waktu Sintasan

\subsection{Menentukan Model Proportional Hazard Weibull}

Analisis sintasan parametrik memiliki baseline hazard yang harus ditentukan. Baseline hazard atau $h_{0}(t)$ merupakan fungsi hazard untuk individu dengan nilai kovariatnya adalah nol. Berdasarkan Tabel 1 dapat diperoleh baseline hazard dalam model proportional hazard Weibull pada pasien stroke adalah sebagai berikut:

Tabel 1. Hasil Analisis Model Proportional Hazard Weibull

$$
\begin{aligned}
\lambda & =\exp \left[\frac{\text {-intercept }}{\text { error variance }}\right] \\
& =\exp \left[\frac{-(-2,767534)}{0,4125289}\right] \\
& =\exp \left[\frac{2,767534}{0,4125289}\right] \\
& =\exp [6,70870332]=819,507311 .
\end{aligned}
$$

\begin{tabular}{|c|c|c|c|c|c|c|}
\hline Variabel & Koefisien & Std. error & $\mathrm{Z}$ & $\mathrm{P}>|\mathrm{z}|$ & \multicolumn{2}{|c|}{$[95 \%$ Conf. Interval] } \\
\hline $\mathrm{X} 1$ & $-0,0215857$ & 0,0091826 & $-2,35$ & 0,019 & $-0,0395832$ & $-0,0035882$ \\
\hline $\mathrm{X} 2$ & $-0,259631$ & 0,2402777 & $-1,07$ & 0,287 & $-0,7268988$ & 0,2149726 \\
\hline $\mathrm{X} 3$ & 0,478261 & 0,3974348 & 1,20 & 0,229 & $-0,3006968$ & 1,257219 \\
\hline $\mathrm{X} 4$ & $-0,0062832$ & 0,2432546 & $-0,03$ & 0,979 & $-0,4830535$ & 0,4704872 \\
\hline $\mathrm{X} 5$ & $-0,0741228$ & 0,3772851 & $-0,20$ & 0,844 & $-0,8135881$ & 0,6653424 \\
\hline $\mathrm{X} 6$ & $-0,306554$ & 0,3139762 & $-0,98$ & 0,329 & -0.921936 & 0,3088281 \\
\hline X7 & $-0,0683181$ & 0,0304425 & $-2,24$ & 0,025 & $-0,1279843$ & $-0,0086519$ \\
\hline Konstanta & $-2,767534$ & 0,8966259 & $-3,09$ & 0,002 & $-4,524889$ & $-1,01018$ \\
\hline $\ln (\mathrm{p})$ & 0,885449 & 0,083253 & 10,64 & 0,000 & 0,7222762 & 1,048622 \\
\hline $\mathrm{p}$ & 2,424073 & 0,2018112 & & & 2,059115 & 2,853715 \\
\hline $1 / \mathrm{p}$ & 0,4125289 & 0,0343443 & & & 0,3504204 & 0,486456 \\
\hline
\end{tabular}

Sumber: Data Diolah, 2018

Sehingga baseline hazardnya menjadi:

$h_{0}(t)=\lambda p t^{p-1}$

$=(819,507311)(2,424073) t^{2,424073-1}$

$=1986,54555 t^{1,424073}$.

Langkah selanjutnya adalah menentukan model proportional hazard Weibull. Berdasarkan Tabel 1, dengan menganggap semua variabel berpengaruh maka model proportional hazard Weibull pada pasien stroke adalah sebagai berikut:

$$
\begin{gathered}
h_{i}(t)=\exp \left(\beta_{1} X_{1}+\beta_{2} X_{2}+\beta_{3} X_{3}+\beta_{4} X_{4}\right. \\
\left.+\beta_{5} X_{5}+\beta_{6} X_{6}+\beta_{7} X_{7}\right) h_{0}(t) \\
=\exp \left(-0,0215857 X_{1}-0,259631 X_{2}+\right. \\
0,4782612 X_{3}-0,0062832 X_{4}- \\
0,0741228 X_{5}-0,306554 X_{6}-
\end{gathered}
$$$$
\left.0,0683181 X_{7}\right) \times 1986,54555 t^{1,424073} .
$$

Langkah selanjutnya adalah menentukan model terbaik dengan dengan menggunakan metode backward elimination. Berikut ini adalah hasil dari backward elimination menggunakan software STATA. 
Tabel 2. Hasil Backward Elimination

\begin{tabular}{|c|c|c|c|c|c|c|}
\hline Variabel & Koefisien & Std. error & $\mathrm{Z}$ & $\mathrm{P}>|\mathrm{z}|$ & \multicolumn{2}{|c|}{$[95 \%$ Conf. Interval] } \\
\hline $\mathrm{X}_{1}$ & $-0,0195386$ & 0,0092673 & $-2,11$ & 0,035 & $-0,03770$ & $-0,001751$ \\
\hline $\mathrm{X}_{7}$ & $-0,0720804$ & 0,0268676 & $-2,68$ & 0,007 & $-0,12474$ & $-0,0194208$ \\
\hline Konstanta & $-2,45037$ & 0,898574 & $-2,73$ & 0,006 & $-4,211511$ & $-0,6892303$ \\
\hline $\ln (\mathrm{p})$ & 0,8598117 & 0,082025 & 10,48 & 0,000 & 0,6990454 & 1,020578 \\
\hline $\mathrm{p}$ & 2,362716 & 0,1938021 & & & 2,011831 & 2,774798 \\
\hline $1 / \mathrm{p}$ & 0,4232418 & 0,0347165 & & & 0,3603866 & 0,4970596 \\
\hline
\end{tabular}

Sumber: Data Diolah, 2018

Berdasarkan Tabel 2 diperoleh model terbaik proportional hazard Weibull yaitu model yang terdiri dari variabel prediktor $\mathrm{X}_{1}$ dan $\mathrm{X}_{7}$. Sehingga dapat ditentukan baseline hazard dari model terbaik proportional hazard Weibull adalah sebagai berikut:

$$
\begin{aligned}
\lambda & =\exp \left[\frac{\text {-intercept }}{\text { error variance }}\right] \\
& =\exp \left[\frac{-(-2,45037)}{0,4232418}\right] \\
& =\exp \left[\frac{2,45037}{0,4232418}\right] \\
& =\exp [5,7895274]=326,858515 .
\end{aligned}
$$

Sehingga baseline hazardnya menjadi:

$$
\begin{aligned}
h_{0}(t) & =\lambda p t^{p-1} \\
& =(326,858515)(2,362716) t^{2,362716-1} \\
& =772,273842 t^{1,362716} .
\end{aligned}
$$

Dengan demikian model terbaik proportional hazard Weibull pasien stroke adalah sebagai berikut:

$$
\begin{aligned}
h_{i}(t)= & \exp \left(-0,0195 X_{1}-0,0721 X_{7}\right) \times \\
& 772,2738 t^{1,362716} .
\end{aligned}
$$

dengan $X_{1}$ menyatakan usia dan $X_{7}$ menyatakan indeks massa tubuh (IMT).

Langkah selanjutnya adalah melakukan uji rasio likelihood yang bertujuan untuk melihat pengaruh variabel-variabel prediktor secara simultan dan menentukan kepentingan relatif dari masing-masing variabel prediktor.

Berdasarkan pada Tabel 3 dapat dilihat bahwa nilai perubahan $-2 \log$ yang digunakan dalam menentukan model terbaik adalah 11,019758 atau model terbaik yang digunakan adalah model yang terdiri dari variabel prediktor $\mathrm{X}_{1}$ dan $\mathrm{X}_{7}$.
Tabel 3. Hasil Analisis Pengujian Rasio Likelihood dengan Pendekatan Distribusi Weibull

\begin{tabular}{|c|c|c|}
\hline $\begin{array}{c}\text { Model dengan } \\
\text { perubahan yang } \\
\text { disertakan }\end{array}$ & -2log likelihood & Perubahan \\
\hline $\begin{array}{c}\text { Tanpa variabel } \\
\text { prediktor }\end{array}$ & 139,27991 & \\
\hline $\mathrm{X}_{1}$ & 135,535306 & 3,744604 \\
\hline $\mathrm{X}_{2}$ & 137,746492 & 1,533428 \\
\hline $\mathrm{X}_{3}$ & 139,25498 & 0,02493 \\
\hline $\mathrm{X}_{4}$ & 138,387126 & 0,892784 \\
\hline $\mathrm{X}_{5}$ & 139,202652 & 0,077258 \\
\hline $\mathrm{X}_{6}$ & 137,164582 & 2,115328 \\
\hline $\mathrm{X}_{7}$ & 132,840984 & 6,438926 \\
\hline $\mathbf{X}_{\mathbf{1}}+\mathbf{X}_{\mathbf{7}}$ & $\mathbf{1 2 8 , 2 6 0 1 5 2}$ & $\mathbf{1 1 , 0 1 9 7 5 8}$ \\
\hline $\mathrm{X}_{1}+\mathrm{X}_{2}$ & 132,583048 & 6,696862 \\
\hline $\mathrm{X}_{2}+\mathrm{X}_{7}$ & 132,272656 & 7,007254 \\
\hline $\mathrm{X}_{1}+\mathrm{X}_{3}$ & 135,49986 & 3,78005 \\
\hline $\mathrm{X}_{3}+\mathrm{X}_{7}$ & 131,966872 & 7,313038 \\
\hline
\end{tabular}

Sumber: Data Diolah, 2018

Langkah selanjutnya adalah melihat ada tidaknya pengaruh nyata variabel prediktor terhadap variabel respons (waktu sintasan) dengan melakukan pengujian secara parsial terhadap masing-masing variabel prediktor.

Berdasarkan hasil pengujian secara parsial data waktu sintasan stroke dengan pendekatan distribusi Weibull yang diperoleh pada Tabel 4, dapat ditunjukkan bahwa variabel yang berpengaruh nyata adalah variabel $\mathrm{X}_{1}$ dan $\mathrm{X}_{7}$ dengan nilai $\mathrm{p}$-value $<0,05$ yaitu masing-masing sebesar 0,019 dan 0,025 . 
Tabel 4. Hasil Uji Parsial Data Waktu Sintasan Pasien Stroke dengan Pendekatan Distribusi Weibull

\begin{tabular}{|c|c|c|c|}
\hline $\begin{array}{c}\text { Variabel } \\
\text { Prediktor }\end{array}$ & $\widehat{\beta_{J}}$ & P-value & Keputusan \\
\hline $\mathrm{X}_{1}$ & $-0,0215857$ & 0,019 & Tolak $H_{0}$ \\
\hline $\mathrm{X}_{2}$ & $-0,259631$ & 0,287 & Terima $H_{0}$ \\
\hline $\mathrm{X}_{3}$ & 0,478261 & 0,229 & Terima $H_{0}$ \\
\hline $\mathrm{X}_{4}$ & $-0,0062832$ & 0,979 & Terima $H_{0}$ \\
\hline $\mathrm{X}_{5}$ & $-0,0741228$ & 0,844 & Terima $H_{0}$ \\
\hline $\mathrm{X}_{6}$ & $-0,306554$ & 0,329 & Terima $H_{0}$ \\
\hline $\mathrm{X}_{7}$ & $-0,0683181$ & 0,025 & Tolak $H_{0}$ \\
\hline
\end{tabular}

Sumber: Data Diolah, 2018

\subsection{Menentukan Hazard Ratio Model Proportional Hazard Weibull}

Hazard ratio dapat digunakan untuk menginterpretasikan koefisien dari variabel prediktor pada model proportional hazard Weibull. Faktor-faktor yang memengaruhi kesembuhan pasien stroke dapat dilihat dari nilai hazard ratio variabel yang berpengaruh secara signifikan.
Berdasarkan Tabel 5 dapat dilihat bahwa nilai hazard ratio untuk variabel $\mathrm{X}_{1}$ sebesar 0,980651, hal ini berarti bahwa untuk peningkatan satu unit pada kovariat usia akan mengurangi risiko kesembuhan sebesar 1,9\%. Sedangkan variabel $\mathrm{X}_{7}$ memiliki nilai hazard ratio sebesar 0,9304561 , hal ini berarti bahwa untuk peningkatan satu unit pada kovariat IMT akan mengurangi risiko kesembuhan sebesar $6,9 \%$.

\section{SIMPULAN DAN SARAN}

\subsection{Simpulan}

Berdasarkan hasil dan pembahasan pada penelitian ini, dari ketujuh variabel prediktor yang digunakan untuk memodelkan kesembuhan pada pasien penyakit stroke hanya terdapat dua variabel prediktor yang berpengaruh nyata terhadap kesembuhan pasien yaitu usia dan indeks massa tubuh (IMT).

\subsection{Saran}

Adapun saran yang bisa diberikan untuk penelitian selanjutnya adalah Pada penelitian selanjutnya dapat menambahkan variabel prediktor lain yang memengaruhi kesembuhan pasien stroke dan kelengkapan informasi pada data yang diperoleh lebih diperhatikan.

Tabel 5. Hasil Analisis Hazard Ratio Model Proportional Hazard Weibull

\begin{tabular}{|c|c|c|c|c|c|c|}
\hline Variabel & Hazard Ratio & Std. error & $\mathrm{Z}$ & $\mathrm{P}>|\mathrm{z}|$ & \multicolumn{2}{|c|}{ [95\% Conf. Interval] } \\
\hline $\mathrm{X}_{1}$ & 0,980651 & 0,009088 & $-2,11$ & 0,035 & 0,9629998 & 0,9986259 \\
\hline $\mathrm{X}_{7}$ & 0,9304561 & 0,249992 & $-2,68$ & 0.007 & 0,8827264 & 0,9807666 \\
\hline $\ln (\mathrm{p})$ & 0,8598117 & 0,0820251 & $-2,73$ & 0,006 & 0,6990454 & 1,020578 \\
\hline $\mathrm{P}$ & 2,362716 & 0,1938021 & 10,48 & & 2,011831 & 2,774798 \\
\hline $1 / \mathrm{p}$ & 0,4232418 & 0,0347165 & & & 0,3603866 & 0,4970596 \\
\hline
\end{tabular}

Sumber: Data Diolah, 2018 


\section{DAFTAR PUSTAKA}

Bastyan, E., \& Latra, I. N. (2013). Analisis Survival dengan Model Regresi Cox Weibull pada Penderita Demam Berdarah Dengue (DBD) di Rumah Sakit Haji Sukolilo Surabaya. Jurnal Sains dan Seni Pomits Vol. 2, No. 2, 2337-3520.

Collet, D. (1994). Modeling Survival Data in Medical Research. London : Chapman and Hall. Cox, D. (1972). Regression Models and Life -Tables. Journal of The Royal Statistical Society. Series B (Methodological), Vol. 34, No. 2 , 187220.

Dinata, A. C., Safrita, Y., \& Sastri, S. (2013). Gambaran Faktor Risiko dan Tipe Stroke pada Pasien Rawat Inap di Bagian Penyakit Dalam RSUD Kabupaten Solok Selatan Periode 1 Januari 2010-3 Juni 2012. Jurnal Kesehatan Andalas, Vol.2, No. 2, 57-61.

Ghani, L., Mihardja, L. K., \& Delima. (2016). Faktor Risiko Dominan Penderita Stroke di Indonesia. Buletin Penelitian Kesehatan, Vol. 44, No. 1, 49-58.

Kemenkes. (2013). Riset Kesehatan Dasar. Jakarta: Badan Penelitian dan Pengembangan Kesehatan Kementerian Kesehatan RI.

Khairatunnisa, \& Sari, D. M. (2017). Faktor Risiko yang Berhubungan dengan Kejadian Stroke pada Pasien di RSU H. Sahudin Kutacane Kabupaten Aceh Tenggara. Jurnal Jumantik, Vol.2, No.1, 60-70.

Kleinbaum, D. G., \& Klein, M. (2005). Survival Analysis A Self-Learning Text. New York: Spinger Science+Business Media, Inc.

Kristiyawati, S. P., Irawaty, D., \& Hariyati, R. T. (2009). Faktor Risiko Yang Berhubungan Dengan Kejadian Stroke Di Rumah Sakit Panti Wilasa Citarum Semarang . J. Keperawatan dan Kebidanan (JIKK), Vol. 1 No. 1, 1-7.

Le, C. T. (1997). Applied Survival Analysis. New York: John Wiley \& Sons, Inc.
Monica, Y. S. A., \& Purhadi. (2016). Analisis Faktor yang Memengaruhi Laju Kesembuhan Pasien Tuberkulosis Paru di RSUD Dr. Soetomo Tahun 2015 Menggunakan Regresi Weibull dan Regresi Cox Proportional Hazard. Jurnal Sains dan Seni ITS, Vol. 5, No. 2, 23373520 .

PERDOSSI. (2011). Guideline Stroke. Jakarta: Perhimpunanan Dokter Spesialis Saraf Indonesia (PERDOSSI).

Ramadany, A. F., Pujarini, L. A., \& Candrasari, A. (2013). Hubungan Diabetes Melitus dengan Kejadian Stroke Iskemik di RSUD dr. Moewardi Surakarta Tahun 2010. Biomedika, Vo. 5 No. 2, 11-16.

Udani, G. (2013). Faktor Resiko Stroke. Jurnal Kesehatan Metro Sai Wawai, Vol.6, No.1, 49-57.

WHO. (2016). Tobacco \& Stroke. Switzerland: WHO Document Production.http://www.wpro.who.int/ch ina/topics/tobacco/tbs-2016-en.pdf.

Wulandari, P. R., (2011)."Penerapan Metode Regresi Least Absolute Shrinkage and Selection Operator (LASSO) Terhadap Waktu Tahan Hidup Penderita Stroke". Skripsi. Jurusan Matematika, Fakultas Matematika dan Ilmu Pengetahuan Alam, Universitas Udayana.

Yogesswara, G. A., Kencana, E. N., \& Sukarsa, I. K. (2018). Estimasi Sintasan Penderita Diabetes Melitus: Komparasi Kinerja Regresi PLS dan LASSO. EJurnal Matematika Vol. 7, No.4, 339-345. 